\section{\#Bitola \\ \#Monastir \\ \#administrative centre \\ \#capital \\ \#Eyalet of Rumelia \\ \#municipality of Bitola \\ Nikola V. Dimitrov \\ Logistics, University Goce \\ Blagoja Markoski*}

Faculty of Tourism and Business

Delchev - Shtip, Macedonia

Faculty of Natural Sciences and Mathematics, Institute of Geography,

University Ss. Cyril and Methodius -

Skopje, Macedonia blagojamarkoski@gmail.com

Ivan Radevski

Faculty of Natural Sciences and Mathematics, Institute of Geography,

University

Ss. Cyril and

Methodius -

Skopje, Macedonia

Vladimir Zlatanoski

Faculty of Natural Sciences and Mathematics, Institute of Geography,

University Ss. Cyril and Methodius -

Skopje, Macedonia

How to cite:

Dimitrov et al. (2017)

Bitola - from Eyalet

capital to regional

centre in the Republic of

Macedonia, Urban

Development Issues,

vol. 55, pp. 67-82 DOI:

10.2478/udi-2018-0006

\title{
Bitola - from Eyalet capital to regional centre in the Republic of Macedonia
}

\section{Abstract}

In the past nine hundred years Bitola has undergone a string of administrative and political rises and falls. In the course of the 16th century the city grew to have a very large population and become a huge economic and geopolitical centre of the large province of Rumelia in the Ottoman Empire. However, as a result of some overwhelming political and military events that played out during the 20th century (the dissolution of the Ottoman Empire, the Balkan wars, WW1, WW2 and other economic, political, technical and technological developments that occurred in the world and in the country) Bitola was reduced to a mere local city in economic, geopolitical and population terms. The immediate economic and population expansion of Bitola is presented through an exact numeric and cartographic overview of spatial-temporal changes in the city's development in the past two centuries. For the purposes of rendering a more accurate image, we have compared Bitola's population, administrative and geopolitical role with a number of major Balkan cities.

submitted: October 2017 reviewed:

December 2017

accepted: February 2018

(C) 2017 Nikola V. Dimitrov, Blagoja Markoski, Ivan Radevski \& Vladimir Zlatanoski. This is an open access article licensed under the Creative Commons Attribution-NonCommercial-

NoDerivs License (http://creativecommons.org/licenses/by-nc-nd/3.0/).

\section{Introduction}

As an urban municipality, Bitola has a multi-millennial history filled with periods of rise and fall. But the most significant period of time was the $19^{\text {th }}$ century because it was a time of many social events that had as their result the demographic and economic progress of the city. Bitola was the administrative seat of the Eyalet of Rumelia, i.e. the Rumelia province, for the first few decades of the $19^{\text {th }}$ century. In the European part of the Ottoman Empire Bitola was a significant administrative, political and economic centre, so according to its significance 
68

it was ranked fifth after Istanbul, Thessaloniki, Bucharest and Edirne. The rise of the city (ranking it $5^{\text {th }}$ to $9^{\text {th }}$ place) lasted almost a century. It was a period of rapid economic, educational and cultural development and a time when Bitola, under significant European influence, became a centre of exceptional military and strategic importance. However, events at the beginning of the $20^{\text {th }}$ century onwards caused this prominent provincial centre to be turned into to a mere border city with limited development - a state lasting an entire century.

\section{Working methods}

The historical events in the geopolitical and social life on the Balkan peninsula in the $19^{\text {th }}$ and $20^{\text {th }}$ century resulted in immense demographic and economic changes in this geographical area. In this context, we will look into the causality of the rise and fall of the city of Bitola as an administrative political, economic and cultural centre at that time. Our research procedure used multiple scientific-research methods which served the purpose of developing a more relevant analysis. More specifically, the methods used were historical, geographical, cartographical and statistical, including also the analytical method and the comparative method. Thus, a combined spatialtemporal overview was developed, identifying the changes in Bitola in particular, but also those occurring more widely across the territory of the Balkans.

Bitola in the $10^{\text {th }}$ century (a short overview) Different periods of development can be identified in the multi-millennial existence of Bitola as an urban settlement. However, particular attention should be paid to the $19^{\text {th }}$ and $20^{\text {th }}$ centuries due to the fact that during the $19^{\text {th }}$ century Bitola was the centre of multiple events favouring the economic and demographic rise of the city.

Significant population growth can be seen in Bitola during the $19^{\text {th }}$ century. In 1805 it had a population of 15,000 ; in 1838 the population grew to 40,000 ; in 1856 to 46,000; in 1889 to 50,050, reaching 60,000 in 1900. This means that in the course of 1805 - 1856 (in 50 years) the population increased by 31,000 or $206.7 \%$, and in the course of $1856-1900$ it increased by 14,000 or $34.4 \%$. The total population growth of Bitola in the $19^{\text {th }}$ century amounted to 45,000 which is a growth of $400 \%$ meaning that the city grew four times (Dimitrov 2005: 7).Population growth in Bitola led to a variety of changes to urban organisation and life in the city. During the $19^{\text {th }}$ century the city started to transform from a typical oriental settlement into a city with a mixed urban and architectural structure which arose as a result of cultural influences from the East and West. One of the reasons for those changes was Bitola's designation as the seat of the Rumelia Eyalet (a province in the Ottoman Empire) in the first decades of the $19^{\text {th }}$ century, which was one of the most significant delegations of the Sultan's power in European Turkey.

The new military-strategic, administrative-political and communication significance that Bitola gained was also due to historical events occurring in the region as a whole, such as the uprisings in Albania, the independence of Greece etc. In this way, and at a time of the Tanzimat reforms in 1835, Bitola became the regional capital of the Rumelia Vilayet, a seat of Rumeli - Valisi, and with the Sultan's Hatiserif of the $21^{\text {st }}$ June 1836 Bitola was officially designated as the main seat of power in Rumelia (Poljanski 1972: 203). Previously Rumelia encompassed all the territories of Macedonia, Thrace and Moesia (Matkovski 1992: 344), covered $124,630 \mathrm{~km}^{2}$, and its seat or capital kept changing. At first it was Edirne (Adrianople), then Sofia and the final one was Bitola or Monastir (Ursinus 1991).

In 1836, Rumelia was partitioned into three new eyalets (Figure 1): Salonica, Edirne and the Rumelia eyalet centred on Bitola/Monastir (Inalcik 1995; Birken 1976).

\section{The administrative-political role of Bitola in the $19^{\text {th }}$ century}

In 1844, Bitola, as the seat of Rumelia, administered an area of $48,907 \mathrm{~km}^{2}$ and a population of 2,700,000. The Ottoman Empire, in 1844, covered an area of 2,938,365 $\mathrm{km}^{2}$, and had a population of $35,350,000$, of which $325,805 \mathrm{~km}^{2}$ (amounting to $11,1 \%$ of the entire area) lay in Europe and had a population of 15,500,000 (amounting to $43.8 \%$ of the total population). Thus, Rumelia and its area covered $1.7 \%$ of the entire territory of the Ottoman Empire, and $15.0 \%$ of the European part of the Empire. Based on its population, Rumelia comprised $7.6 \%$ of the Empire, that is, $17.4 \%$ of the European part of the Empire (Matkovski 2000: 253-255, 346; excerpt from the travel book of James Lewis Farley from 1861-1869). Under its management were: the present day Republic of Macedonia, Kosovo, parts of Albania, Serbia, Bulgaria, Montenegro and Greece (Table 1, Figure 2). Administratively, Rumelia was divided into multiple vilayets (the vilayets of Bitola, Skopje, Salonica etc.). The Vilayet of Bitola was composed of 5 sanjaks: Bitola, Prizren, Skopje, Debar and Scutari.

Bitola, apart from being the seat of the province of Rumelia, was also designated as its capital, while Thessaloniki - the main port of Macedonia - was the second city of Rumelia. According to James Lewis Farley (a British financial expert in the Ottoman Bank who lived in Turkey for a long time and knew the state of the Empire, and particularly of Macedonia): "Bitola was a large city in Rumelia and the capital of one of the rich eyalets (the Bitola Eyalet-Sanjak) in the European part of Turkey... 
Salonica (Thessaloniki) was the main port of Macedonia, and second most important city in Rumelia (Matkovski 2000: 348; J. L. Fisher's travelogue from 1861 to 1869 ).

This situation remained unchanged until 1867, when the eyalet system was replaced by vilayets, and so 5 vilayets were formed out of the Rumelia Eyalet: Bitola, Salonica (1867-1912), Kosovo (Skopje; 1877-1913; among which the ethnic territory of Macedonia was divided), as well as Scutari and Elbasan (Figure 2).

During the entire $19^{\text {th }}$ century Bitola strengthened its role as a vilayet (provincial) centre, thus annexing multiple smaller administrative units: sanjaks, kazas and nahiyahs. Towards the end of the 1850s and beginning of the 1860s the Vilayet of Bitola was partitioned into three sanjaks: Bitola, Ohrid and Korcha. The Bitola Pasha Sanjak was comprised of 11 kazas. The Bitola Eyalet had a population of $1,397,646$ and the city of Bitola 46,000 (Senkevich 1967: 117; Sotirovski 1966: 189-190; Stamboliska 2005: 34).

Towards the end of the $19^{\text {th }}$ century, the Bitola Vilayet covered a surface area of 32,000 $\mathrm{km}^{2}$ and included Macedonian, Albanian and Greek territories with a total population of 800,000 $-900,000$. It was made up of 5 sanjaks (the Bitola, Debar, Korcha, Elbasan and Serfiçe sanjaks) with a total of 22 (23) kazas and 26 (27) nahiyahs. The Sanjak of Bitola consisted of 5 kazas and 9-10 nahiyahs. Out of 708 settlements in total, 266 belonged to the Bitola Kaza (37.6\%), while the remaining 442 settlements $(62.4 \%)$ belonged to the remaining kazas (Dimeski 1982: 81-87).

In the $1870 \mathrm{~s}$, the total area of the Macedonian territories $\left(58,648 \mathrm{~km}^{2}\right.$ with a total population of $1,190,000)$ was divided into the following sanjaks: Salonica (Thessaloniki), Seres, Drama, Iskub (Skopje) and Bitola. Bitola, as the seat of the Bitola Sanjak, administered a surface of $18,440 \mathrm{~km}^{2}$ (or $31.4 \%$ of the total surface of all Macedonian territories) and with a population of 379,000 or $31.8 \%$ of the total population living on all Macedonian territories (Matkovski 2001: 212; calculations according to travellers F. Hellward and L. Beck from around 1877).

\section{Economic development}

Its new military and administrative position enabled the city of Bitola to rapidly develop, first as a craft and trade centre, and then also as a sociopolitical, educational, religious and cultural centre in the south-western part of Macedonia and in the Balkans as a whole. Therefore, Bitola quickly became the centre for making preparations for huge military actions to defend the area against more frequent attacks by looters, such as the one in 1806 when the city was plundered by Ali Pasha Yaninsky (Kjoropanov 1986: 19-20) and others in 1832 and 1833 etc.

\section{Artisanship}

The most significant advance seen among all the economic sectors in the city was made by artisanship. The period of the $19^{\text {th }}$ century was known as "the golden age of artisans" in Bitola. Thus in 1827 there were 30 esnafs (association of craftsmen) in Bitola (Bitoski 1966: 137-163) with over 70 different types of artisan craft (Konstantinov 1961: 163) and over 1400 shops and workshops (Turkish documents on Macedonian history 1958: 1719).

According to data from the $1837 / 38$ census, 70 types of Bezisten (covered market) with 86 shops, two pottery tile manufacturer, 30 watermills, 10 bakeries, 12 taverns, 2 12 inns, 4 hamams (Turkish baths) etc. (Turkish documents history 1996: 153-217) were recorded in Bitola. At that time citizens were directly connected to artisanship, and along with number supported by this activity amounted to nearly 8,000 nearly three quarters (75\%) of the population of the city income from artisan shops (Dimitrov 2005: 9).

Trade also developed in parallel with the artisan industries 1838, there were over 800 tradesmen working in Bitola. Most inside the Ottoman Empire, but a few also traded with Western Europe, and Persia as well as India. (This is document from 1829, in which it states that the tradesman from Bitola traded "on land and sea with Western Europe, (Turkish documents on Macedonian history 1958: 53-56).

In 1862, artisanal products from Bitola were present at the International Exhibition in London. They were the result of hard work of 2,065 shops, with about 140 types of different

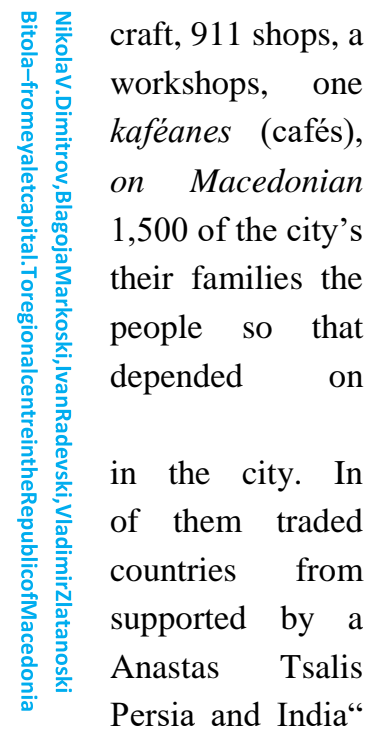
Persia and India“" and professions and over 70 esnaf organizations (Konstantinov 106). In 1876, the official Turkish records listed 1650 shops, 150 magazas (emporiums), 50 taverns, 37 watermills, 93 bakeries, 10 kafeanes, 5 tile manufacturers, 3 magazas for clothes, 25 taverns, 1 post office, 15 pharmacies, and 15 petroleum storage facilities in the Bazaar of Bitola,

figure 1

Bitola Vilayet in Rumelia Eyalet in 1850 

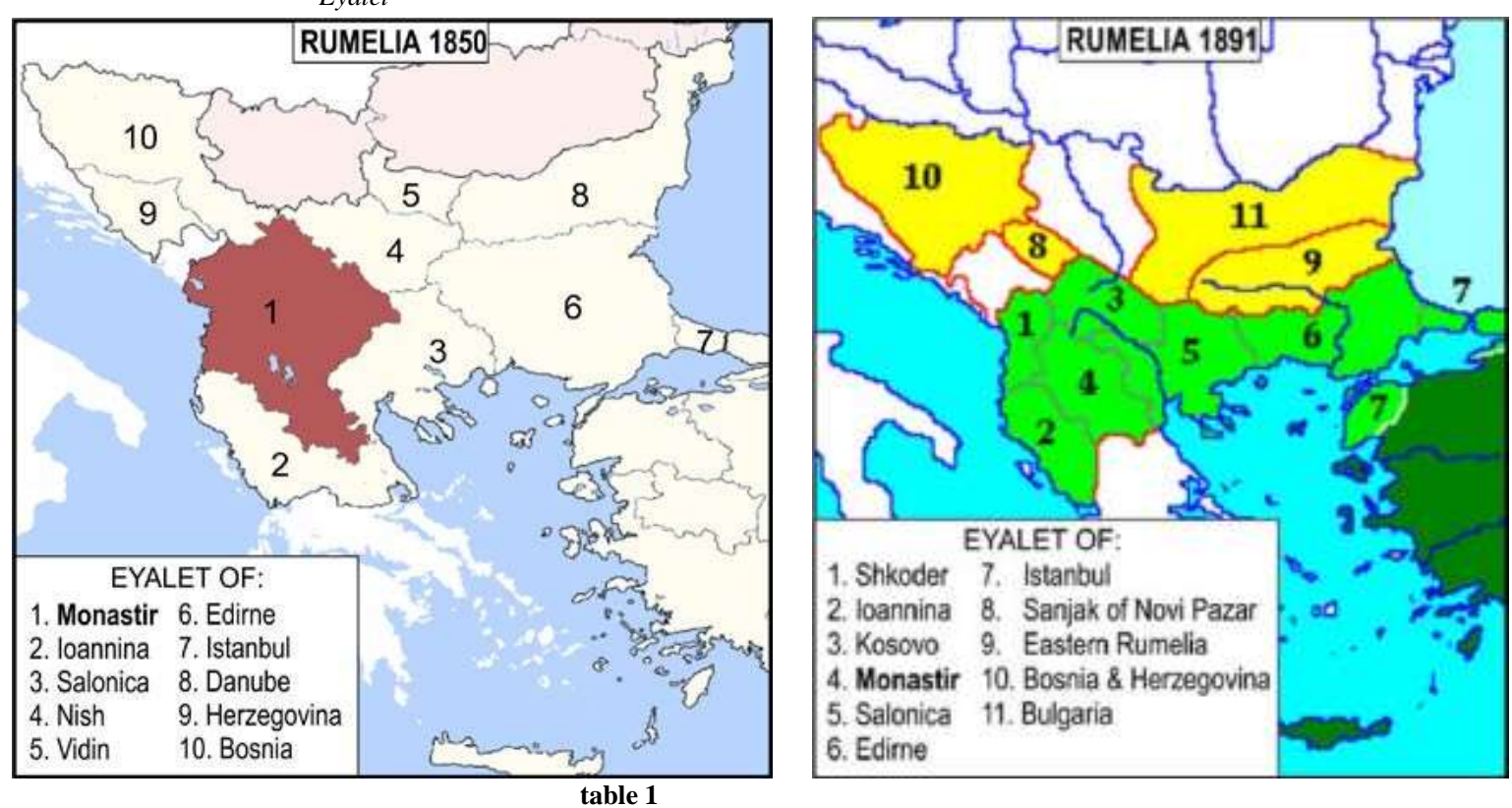

figure 2

Bitola Vilayet in Rumelia 1885-1900

Source: own elaboration based on World history..

Bitola - a vilayet (province) seat, from 1836 to 1912 (comparison with other border vilayets)

Source: own elaboration based on Monastir Vilayet, Salonica Vilayet, Kosovo Vilayet and

Scutari Vilayet

\begin{tabular}{llcrl}
\hline Vilayet & Period & Surface $\mathbf{k m}^{2}$ & \multicolumn{2}{c}{ Population (year) } \\
\hline $\begin{array}{l}\text { Rumelia with Bitola as its } \\
\text { seat }\end{array}$ & 1836 & 124,630 & $8,000,000$ & (estimate) \\
\cline { 2 - 5 } & 1844 & 48,907 & $2,700,000$ & $(1844)$ \\
\hline Bitola & $1858-1862$ & 33,000 & $1,397,646$ & $(1862)$ \\
\hline Bitola & $1874-1877$ & 32,000 & $1,069,789$ & $(1911)$ \\
& $1879-1912$ & 30,000 & 900,000 & $(1912)$ \\
\hline Salonica & $1867-1912$ & 33,500 & $1,347,915$ & $(1911)$ \\
\hline Skopje- Kosovo & $1877-1913$ & 30,000 & $1,602,949$ & $(1911)$ \\
\hline Scutari & $1867-1913$ & 13,800 & 349,455 & $(1911)$ \\
\hline Yanina & $1867-1913$ & 47,400 & 560,835 & $(1911)$ \\
\hline
\end{tabular}

2,000 artisans in Bitola and 1,000 tradesmen meaning more luxury houses, around ten consular residencies, few that both groups together supported nearly 15,000 people Orthodox Churches, a Catholic church, baths, storehouswhich was almost a third (33-35\%) of the city. It can there- es, neighbourhood mosques etc. Old streets were widened fore be claimed, with certainty, that in the first decades and there was ongoing construction of new streets, bridgof the $19^{\text {th }}$ century Bitola was a strictly artisan city, while es, a public aqueduct, public taps and fountains, a city for the remainder of the century it acquired the epithet park, a library, hotels, factories, a home for orphans and

"an artisan and commercial city" (Dimitrov 2005: 13). the poor, a railway (1894), multiple photography studios, various associations, many residential houses in old 
although there weren't any factories, which amounted to a total of 2,054 active economic entities in Bitola (Petkova 1993/1994: 138).

\section{Trade}

In 1865, there were 40 bigger and 340 smaller tradesmen operating in Bitola, however some foreign tradesmen were also involved, as well as branches of many trade houses. Many trading companies from Bitola had their subsidiaries in Thessaloniki, Vienna, Peshta, Leipzig, Berlin, Trieste, Venice, London, Paris, Marseille, Zadar, Sarajevo, Belgrade, Sophia, Plovdiv, Scutari, Tsarigrad, Alexandria and other important trade centres. Intensive export-import trading relations were maintained with Russia, France, England, Switzerland, Bulgaria, Serbia, Romania, Italy, Prussia (Germany), Egypt, Persia, India and other countries (Zografski 1967: 362; Poljanski 1972: 203-219).

Toward the end of the $19^{\text {th }}$ century, there were over
The total number of people employed in the industrial sector in Bitola was over 2,000 people. Up to 10,000 people i.e. $20 \%$ of the entire city population, found their means of support, either directly or indirectly, in the city's industry. All in all, towards the end of the $19^{\text {th }}$ century half of Bitola's population obtained their means of support through craft shops, trade or industry (Dimitrov 2005: 22).

\section{Building industry}

In the course of the $19^{\text {th }}$ century, building was another industry that underwent intensive development, and this is when the construction of brick and stone buildings and structures began. Two large barracks were built (1838/1848), also two post-offices (1848), a military gymnasium (1882), a state konak-saraj (1886), hundreds of shops, warehouses, workshops, a few banks, three military and four civilian hospitals, multiple schools, a theatre (1898), training of the the Dragor river by embankments (1896), a few orthodox churches $(1830,1863,1870)$, many 
the construction of two factories: one for the production of beer and spirits and the other for the production of oil (Zografski 1967: 472-476). They were followed a bit later by the opening of a state printing house, as well as a few textile and knitwear factories, candy and Turkish delight factories, tile factories etc.

The first industrial factories in Bitola appear in 1883 In 1897 , there were already 12 textile factories and 8 water-powered flour mills in operation. It is not surprising then that towards the very end of the $19^{\text {th }}$ century Bitola's industry consisted of 24 industrial factories, including 3 flour mills, 1 brewery, 2 other food companies, 4 textile factories, 8 wood working factories, 4 printing house, 1 leather and sole factory and 1 tile production factory (Zografski 1967: 144). offices (first the Austrian and then the Turkish post office opening in 1848). The year 1861 marked the beginning of the operation of Bitola's postal and telegraph lines, one of them starting in Bitola, through Skopje, Pristina to Belgrade; another from Bitola through Thessaloniki to Tsarigrad; then from Bitola through Korcha to Yanina, and Bitola was also a city of transit of the telegraph line connecting England to India (Dimitrov 1998: 55-56).

\section{Education}

All throughout the $19^{\text {th }}$ century Bitola was an important education centre with twenty boys and girls schools, as well as a cultural centre with a theatre, libraries, music, sport and other associations. It was also 
a city that participated in many exhibitions and fairs, a city

\section{Banking}

neighbourhood units as well as new apartment complex-

The size of the city is also evident from its banking sys- es, quarters etc. This says a lot about the city also being tem represented through the subsidiaries of the Ottoman a vast building site and providing support for thousands Bank (1863), the Thessaloniki bank (1888), the Ottoman of people (Dimitrov 1998: 48-89).

Agricultural bank - Zirat bank (1893), other smaller banks and multiple private bookmakers (Zografski 1967: 467). Traffic

There was a significant improvement in the transport con-

\section{Industry}

The first manufacturing workshops in Bitola date from Thes 1860 and 1864, when a Swiss company from Zurich started work of two post

with around ten consuls, a cosmopolitan city bringing the orient and Western Europe together.

All of these data lead us to the conclusion that for the major part of the $19^{\text {th }}$ century Bitola was one of the leading artisan capitals in the Ottoman Empire, after Tsarigrad, Thessaloniki, Smirna, Alexandria, Baghdad and Damascus. In European Turkey however, Bitola ranked third for development of the economy and craftsmanship, just behind Tsarigrad and Thessaloniki, and finally it ranked first in the boundaries of the Balkan Peninsula, as a leading city - the very capital of artisan-

72 ship throughout the entire $19^{\text {th }}$ century. Bitola's leading position at that time is an undisputable fact.

The words of the British politician and diplomat Henry Lear bear testimony to the economic rise of Bitola in the $19^{\text {th }}$ century. In 1839 , while strolling through town, he noticed the following: "Bitola is a large city and the capital of Rumelia... the city markets are huge and well stocked with home and foreign goods and products" (Matkovski \& Angelkova 1974: 236-237).

A similar comment stands in the report of the British consul in Bitola, John A. Lonwort, from 1852, who among other things noted the following “....even more than any other city I have seen on the nections of Bitola during the course of the $19^{\text {th }}$ century, which was due to the construction of roads towards saloniki, Prilep and Ohrid, as well as the

mainland, it has the presence of commercial movement, renewal and prosperity" (Poljanski 1982: 148-150).

Edward Spenser, who visited Bitola in 1850, remarked among other things that "The city is the seat of the Vezir of Rumelia and has a population of 50,000, modern public buildings, infantry barracks, a hospital, a palace for the Vizier and others, it has a European look, a multitude of mosques, narrow streets and wooden houses, a monastery...various caravans pass through the city, with camels, mules and leather, commercial activity of Spanish Jews who are said to be immensely rich,...there are also Armenians, Greeks leading the commerce in the city,... cutlery of Australian production, English produce, forks, spoons, British silver, selling of British produce,...a picnic in the city..." (Matkovski 1992: 50-60).

Data on the population of Bitola, compared to other cities of the Balkan Peninsula, also speak in context of what is described above (Table 2, Figure 3, Figure 4).

Bitola, in certain years during the $19^{\text {th }}$ century, had a larger population than many European cities that are far more populated 
and famous today. It is evident from the data above that Bitola ranks fifth by population density in the Balkans in the 1800-1869 period, but ranks among the top ten cities due to its size in the 1870-1900 period (Figure 4). Compared to some European cities it can be concluded that in the $19^{\text {th }}$ century Bitola was larger than a number of cities such as Kiev, Kharkiv, Minsk, Bern, Bratislava, Krakow, Belgrade, Sofia and many others.

\section{Bitola in the $20^{\text {th }}$ century (a short overview)}

The first and second decade of the 20th century featured some events in the Balkans and in Macedonia that impeded Bitola's rise. These include the following historical events: the Ilinden uprising in 1903; the Balkan wars in 1912 and 1913; the partition of Macedonia in 1913 and WW1 from 1914 to 1918, which together caused a drastic geopolitical, economic and population decline of Bitola. These events basically limited Bitola's further economic and geopolitical development.

So in Bitola, the $20^{\text {th }}$ century started by a change of "rulers", meaning that the Turkish people left the historical scene in 1912 after 530 years of rule in Bitola and Macedonia in general, and were followed by the Serbs who took over from 1912 to 1914, and the Bulgarians and Germans who arrived in Bitola from 1914 to 1918.

After the Ilinden uprising, the Balkan Wars, and especially during WW1 and as a result of constant bombing, Bitola underwent the heaviest economic and population decline ever. The population decreased from about 60,000 to 23,000 - a decrease of $61.7 \%$, meaning that Bitola suffered an almost complete exodus of the city's population.

From 1919 to 1941 Bitola was part of the Kingdom of the Serbs, Croats and Slovenes (1919-1929), which then changed the name to

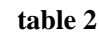

The population of Bitola compared to other cities of the Balkan peninsula in the course of the 19th century Source: Relevant census data for each city the Kingdom of Yugoslavia (19291941). In 22 years, in spite of the border barrier towards the South and Thessaloniki, Bitola achieved a significant economic and population growth, so in 1937 its population reached 33,024 (Grujoski 1971: 67; Dimitrov 1998: 83, 86). In the 1921-1931 period, Bitola was the centre of Bitola County with an area of $5,803 \mathrm{~km}^{2}$ and a population of 176,732 (Table 3). From 1931 to 1941 Bitola was the centre of a significantly smaller area of $1,798 \mathrm{~km}^{2}$ and a population of 65,164 (Table 4, Figure $5)$.

During WW2 (1941-1944) the city was under Bulgarian and German rule and the city at that time had a population of 28,405 (Dimitrov 1998: 68, 83, 87). But in spite of that, Bitola remained the centre of the Bitola area which covered an area of $6,442 \mathrm{~km}^{2}$ and had a population of 250,000 (about $25 \%$ of the area and $22.7 \%$ of the population in relation to today's territory of the Republic of Macedonia).

After WW2, from 1944 to 1991 (a 47-year period), one part of Macedonia, as a federal unit, first named Narodna (People's) and afterwards known as Socijalistichka (Socialist) Macedonia, formed part of the PFRY i.e. SFRY. This was a time of rapid economic and population growth when, despite intense emigration, Bitola became the second city in the SR of Macedonia with a population of 84,002 according to the census of 1991 (Dimitrov 1998: 83, 91-101). At the same time, again based on its popula- 
$1870-1900$

\begin{tabular}{|c|c|c|c|}
\hline Place & Name of city & & Population \\
\hline 9 & Bitola & 18891900 & 50,050 \\
\hline \multirow[t]{2}{*}{7} & & & around \\
\hline & & & 60,000 \\
\hline 1 & Istanbul & 1895 & 900,000 \\
\hline 4 & Thessaloniki & 18701890 & 90,000 \\
\hline 4 & & & 118,000 \\
\hline 2 & Bucharest & 18771889 & 177,646 \\
\hline 2 & & & 282,071 \\
\hline 6 & Edirne & 1900 & 68,661 \\
\hline 5 & Subotica & 18801890 & 62,556 \\
\hline 5 & & & 74,250 \\
\hline 3 & Athens & 1896 & 123,000 \\
\hline 8 & Belgrade & 1878 & 50,000 \\
\hline 11 & Skopje & 18781892 & 30,000 \\
\hline 16 & & & 34,152 \\
\hline 10 & Zagreb & 18801890 & 30,830 \\
\hline 13 & & & 40,268 \\
\hline 8 & Belgrade & 1878 & 50,000 \\
\hline 15 & Sofia & 18801892 & 20,501 \\
\hline 10 & & & 46,628 \\
\hline 19 & Sarajevo & 1878 & 20,000 \\
\hline \multirow[t]{2}{*}{26} & Tirana & 1890 & 14,000 \\
\hline & Ljubljana & 1890 & 30,505 \\
\hline \multicolumn{4}{|l|}{16} \\
\hline 23 & Pristina & 1890 & 16,000 \\
\hline 15 & Varna & 1887 & 25,256 \\
\hline 20 & Novi Sad & 18701890 & 19,301 \\
\hline 17 & & & 24,717 \\
\hline 16 & Plovdiv & 18801892 & 24,053 \\
\hline 15 & & & 36,033 \\
\hline & Nish & 1890 & 19,877 \\
\hline \multicolumn{4}{|l|}{18} \\
\hline 21 & Split & 1890 & 18,483 \\
\hline 13 & Russe & 1880 & 26,163 \\
\hline
\end{tabular}




\begin{tabular}{llll}
\hline 12 & Rijeka & 18801900 & 27,904 \\
9 & & & 51,419 \\
\hline 14 & Patras & 1896 & 37,985 \\
\hline 8 & Timișoara & 1900 & 53,033 \\
\hline 14 & & & \\
11 & Craiova & 18981900 & 39,000 \\
& & & 45,438 \\
\hline
\end{tabular}


$1800-1869$

\begin{tabular}{|c|c|c|c|}
\hline Place & Name of city & & Population \\
\hline 5 & Bitola & 1838 & 40,000 \\
\hline 5 & & 1856 & 46,000 \\
\hline 1 & Istanbul & 1800 & 570,000 \\
\hline 1 & & 1850 & 785,000 \\
\hline 2 & Thessaloniki & 1842 & 70,000 \\
\hline 3 & & 1850 & 80,000 \\
\hline 3 & Bucharest & 1831 & 60,587 \\
\hline 2 & & 1859 & 121,734 \\
\hline 4 & Edirne & 1800 & 40,000 \\
\hline 6 & Subotica & 18361869 & 32,984 \\
\hline 4 & & & 57,556 \\
\hline 11 & Athens & 18331869 & 14,000 \\
\hline 6 & & & 44,500 \\
\hline 12 & Belgrade & 18381850 & 12,963 \\
\hline 6 & & & 40,000 \\
\hline 9 & Skopje & 18311841 & 22,960 \\
\hline 9 & & & 25,095 \\
\hline 14 & Zagreb & 18051857 & 7,706 \\
\hline 10 & & & 16,657 \\
\hline 12 & Belgrade & 18381850 & 12,963 \\
\hline 6 & & & 40,000 \\
\hline 16 & Sofia & 18401869 & 15,000 \\
\hline \multirow[t]{2}{*}{10} & & & 19,000 \\
\hline & Sarajevo & & \\
\hline 15 & Tirana & 1820 & 12,000 \\
\hline 17 & Ljubljana & 1800 & 10,000 \\
\hline 8 & & 1869 & 22.600 \\
\hline \multirow[t]{2}{*}{17} & Pristina & 1850 & 12,000 \\
\hline & Varna & & \\
\hline \multirow[t]{2}{*}{10} & Novi Sad & 1848 & 18,530 \\
\hline & Plovdiv & & \\
\hline 9 & Nish & 18361850 & 16,000 \\
\hline 14 & & & 12,000 \\
\hline \multirow[t]{2}{*}{13} & Split & 1857 & 12,417 \\
\hline & Russe & & \\
\hline 12 & Rijeka & 1850 & 15,000 \\
\hline 11 & Patras & 1853 & 15,854 \\
\hline
\end{tabular}




\begin{tabular}{llll}
\hline 10 & Timișoara & 18471869 & 18,103 \\
7 & & & 32,725 \\
\hline 12 & Craiova & 18211859 & 13,000 \\
7 & & & 30,000 \\
\hline
\end{tabular}


figure 3

Population in the city of Bitola and major Balkan cities in the period 1800-1869

Source: own elaboration based on relevant census data

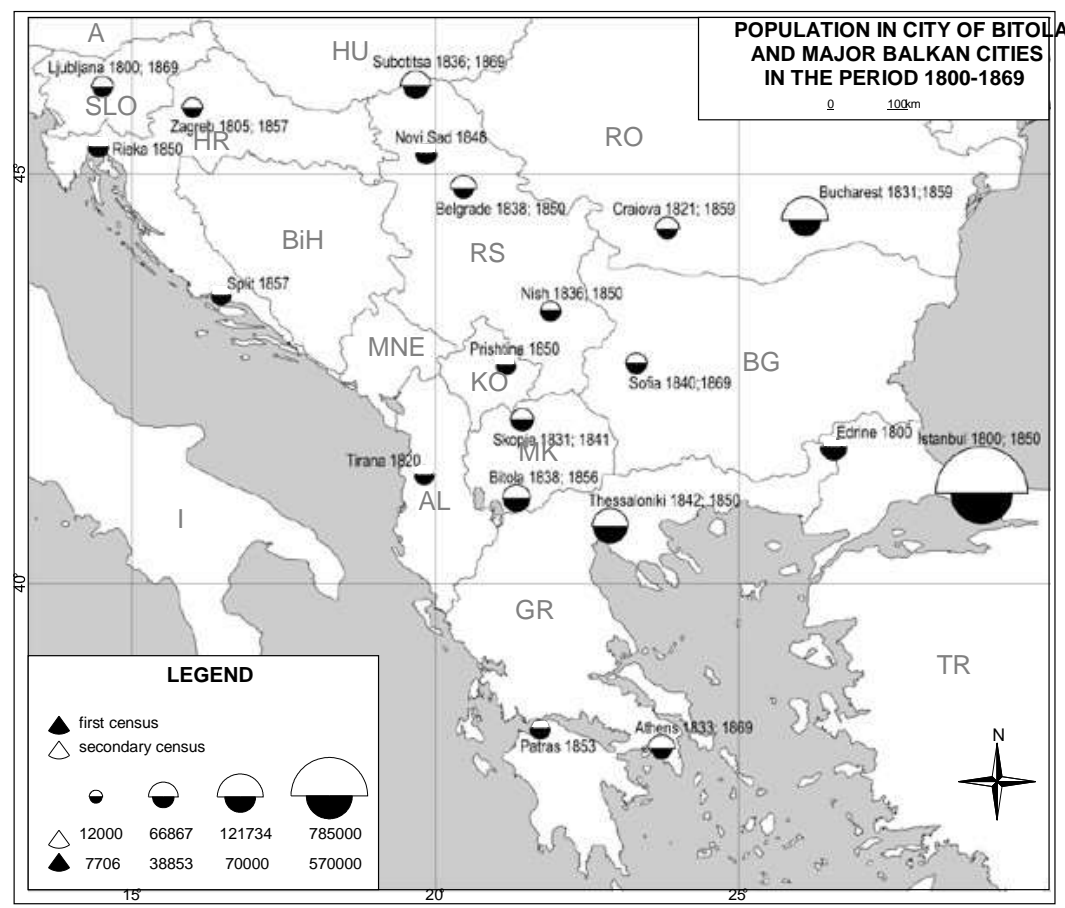

figure 4

Population of the city of Bitola and major Balkan cities in the period 1870-1900 Source: own elaboration based on relevant census data tion, it ranked $18^{\text {th }}$ in the SFR of Yugoslavia, and ranked $35^{\text {th }}$ in the Balkans (Table 4, Figure 6).

In the period from 1944 to 1991 the role of Bitola as a territorial administrative centre changed a number of times. In the period from 1945 to 1951 , it was the centre of Bitola County and covered an area of $1,798 \mathrm{~km}^{2}$ or $7.0 \%$ with a population of 90,295 or $7.8 \%$ according to the census of 1948. In the period from 1952 to 1960 it was responsible for $2241 \mathrm{~km}^{2}$ or $8.7 \%$ with a population of 121,546 or $9.3 \%$ according to the census of 1953. In the period from 1961 to 1965 , Bitola was the centre of the Bitola County, covering $4154 \mathrm{~km}^{2}$ or $16.1 \%$ with a population of 235,382 or $16.7 \%$ according to the census of 1961 (Dimitrov \& Ognenovski 2009: 90-92).

From 1965 to 1995 Bitola was the centre of the Municipality of Bitola, which covered an area of 1,798 $\mathrm{km}^{2}$ or $7.0 \%$ with a population of 124,512 or $7.5 \%$ according to the census of 1981 and 108,203 or $5.6 \%$ according to the census of 1994 (Dimitrov \& Ognenovski 2009: 95-99).

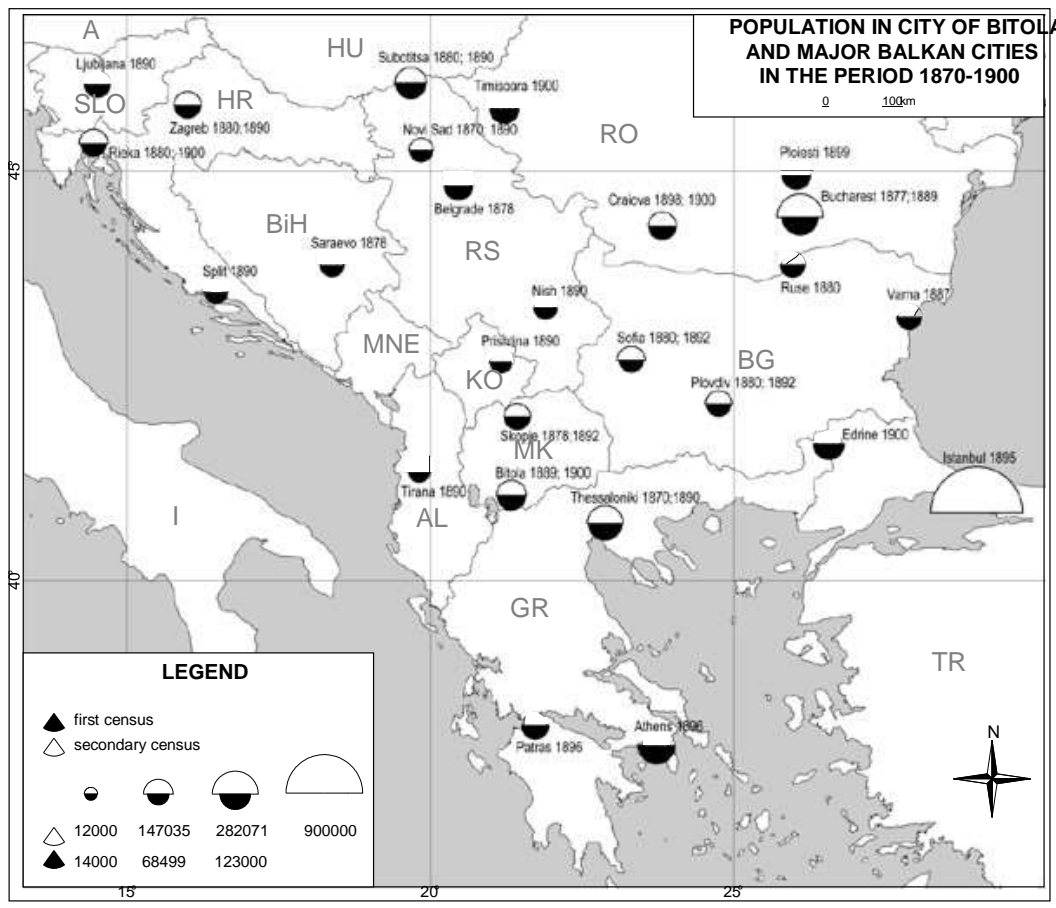

With the new administrative divisions applying in the period from 1995 to 2004, Bitola governed a very small area of only 233 $\mathrm{km}^{2}$ or $0.9 \%$ of the surface of the Republic of Macedonia with a population of 95,385 or $4.7 \%$ of the total population, according to the 2002 census. With the most recent administrative territorial divisions introduced in 2004/5 Bitola governed $792 \mathrm{~km}^{2}$ or $3.1 \%$ of the territory of the Republic of Macedonia with a population of 95,385 or $4.7 \%$ of the total population of the Republic of Macedonia (Dimitrov \& Ognenovski 2009: 101-106). 
A significant improvement of Bitola as the centre of an administrative unit of territory is achieved by NUTS, the regional divisions of the Republic of Macedonia, from 2008 when Bitola becomes the centre of the Pelagonia statistical planning region, and the regional town of a region with an area of $4,710 \mathrm{~km}^{2}$ or $18.3 \%$ of the Republic of Macedonia with a population of 238,136 or $11.8 \%$ of the total population according to the census from 2002 (Dimitrov \& Ognenovski 2009: 109-110).

In 1991, the Republic of Macedonia obtained its independence and sovereignty, and Bitola, in spite of its demographic, economic and other problems and with a population of 74,550 is still the second biggest city in the country on the basis of its population.

In the absence of a relevant census, according to our own estimate in 2015 and due to trends in natural change and emigration, the population of Bitola varies between 70,000 and 80,000, which places it third by size in the Republic of Macedonia, just behind Skopje and Kumanovo, while on a Balkan level it is somewhere between $45^{\text {th }}$ and $50^{\text {th }}$ place (Table 4 , Figure 7).

The urban-territorial and economic-functional development of bitola in the 20th century

In addition to the impacts on the population and administrative division of territory, Bitola in the 20th century is characterised by extreme urban-territorial and economic-functional developmental features. Because of historical developments (the Macedonian Ilinden Uprising in 1903, the Balkan Wars 1912/13, the WW1 19141918), Bitola declined from a city with about 60,000 inhabitants in 1900 , to one of around 27,000 in 1921. In the intervening period (with Bitola lying on the front line of the WW1),

845 houses were burnt, 619 buildings were demolished, and 696 buildings and 119 houses were damaged (Dimitrov \& Ognenovski 2009: 126).

table 3

Bitola - centre of administrative divisions over the past 200 years *

In 2008, a division using NUTS regions was implemented in

Macedonia; in this division Bitola is a center of a region with an area of $4710 \mathrm{~km}^{2}$, but data about population is from 2002 as this is

the last official census data available for the Republic of Macedonia

Source: State Statistical Office of the Republic of Macedonia,

population censuses 1948-2002 and Dimitrov 1998: 86, 94, 113.
But the previous significance of Bitola was an incentive for the development of new administrative-political, territorial and economic functional structures. This development began to take place during the Serbian colonisation of the Vardar part of Macedonia from 1918-1941, and in particular continued to be evident after the WW2. Thus Bitola, despite the mass emigration of the population (mainly overseas to the United States, Canada and Australia) witnessed a growth in population (with the immigration of the young rural population) and urban-territorial spread. The urban area of the city previously about $20 \mathrm{~km}^{2}$, extended to about $26 \mathrm{~km}^{2}$, or by $23 \%$ (Dimitrov \& Ognenovski 2009: 126) following the 1960s and especially the 1970s. The reason was accelerated industrialisation, development of the REK thermal power plant in the 1970s, the construction and development of line and institutional infrastructure, so according to the economicfunctional arrangements, only governmental administrative (legislative and executive) institutions and a clinical centre are today absent in Bitola. Accordingly, it maintains the epithet of a regional centre of second rank and function (after the capital Skopje) in the Republic of Macedonia. There are university institutions in Bitola, and the diplomatic and consular missions have been renewed (as in the period before the Balkan Wars of 1912-13).

The resolution of urban overcrowding in Bitola (and in general in the cities of the Republic of Macedonia) is possible with better organisation of agricultural production and ranking, the urban and infrastructural arrangement of the rural environment, and by dispersion of the vital institutional infrastructure to larger rural centres.

\section{Conclusions and recommendations}

In the past 200 years, Bitola has known intensive economic, geopolitical and population changes. From the data presented it is obvious that in the $19^{\text {th }}$ century,

75 Bitola's geopolitical, strategic and administrative political position (a centre in the western provinces of the Ottoman Empire) 


\begin{tabular}{|c|c|c|c|}
\hline \multirow[t]{2}{*}{ Rumelia Eyalet } & $1836-1844$ & 48,907 & $2,700,000 \quad(1844)$ \\
\hline & 1858-1867 & 33,000 & $1,397,646 \quad(1862)$ \\
\hline \multirow[t]{3}{*}{ Bitola Vilayet/Sanjak } & $1890-1900$ & 32,000 & $1,069,789 \quad(1900)$ \\
\hline & $1903-1910$ & 32,000 & $900,000 \quad(1910)$ \\
\hline & 1912 & 32,000 & 663,027 (1912) \\
\hline \multirow{2}{*}{$\begin{array}{l}\text { Bitola Srez } \\
\text { (larger arounding area) }\end{array}$} & 1921-1931 & 5,803 & 176,732 (1921) \\
\hline & 1931-1941 & 1,798 & 65,164 (1931) \\
\hline Bitola Area & 1941-1944 & 6,442 & 250,000 (estimate) \\
\hline \multirow{2}{*}{\multicolumn{4}{|c|}{$\begin{array}{l}\text { (Bitola, Brod, Krushevo, Prilep, Ohrid, } \\
\text { Resen,Demir Hisar.) }\end{array}$}} \\
\hline & & & \\
\hline \multirow{4}{*}{$\begin{array}{l}\text { Bitola county } \\
\text { (1953 -Bitola, Demir Hisar.) } \\
\text { (1961 - Bitola, Demir Hisar, Krushevo,Prilep) }\end{array}$} & 1945-1948-1951 & 1,798 & 90,295 (1948) \\
\hline & $1952-1954-1960$ & 2,241 & $121,546 \quad(1953)$ \\
\hline & 1961-1962-1965 & 4,154 & $235,382 \quad(1961)$ \\
\hline & & & $111,581 \quad(1961)$ \\
\hline \multirow[t]{5}{*}{ Municipality of Bitola } & 1965-1971-1981-1994- & 1,798 & $124,512 \quad(1971)$ \\
\hline & 1995 & & $137,636 \quad(1981)$ \\
\hline & & & $124,003 \quad(1991)$ \\
\hline & & & $108,203 \quad(1994)$ \\
\hline & 1996-2002-2004 & 233 & $95,385 \quad(2002)$ \\
\hline Pelagonia Region (Bitola, Resen, Demir & since 2008 (new administrative & 4,710 & 238,136 (2002) \\
\hline Hisar, Prilep, Dolneni, Novaci, MMgila, & division)* & & \\
\hline Krushevo, Krivogashtani.) & & & \\
\hline
\end{tabular}




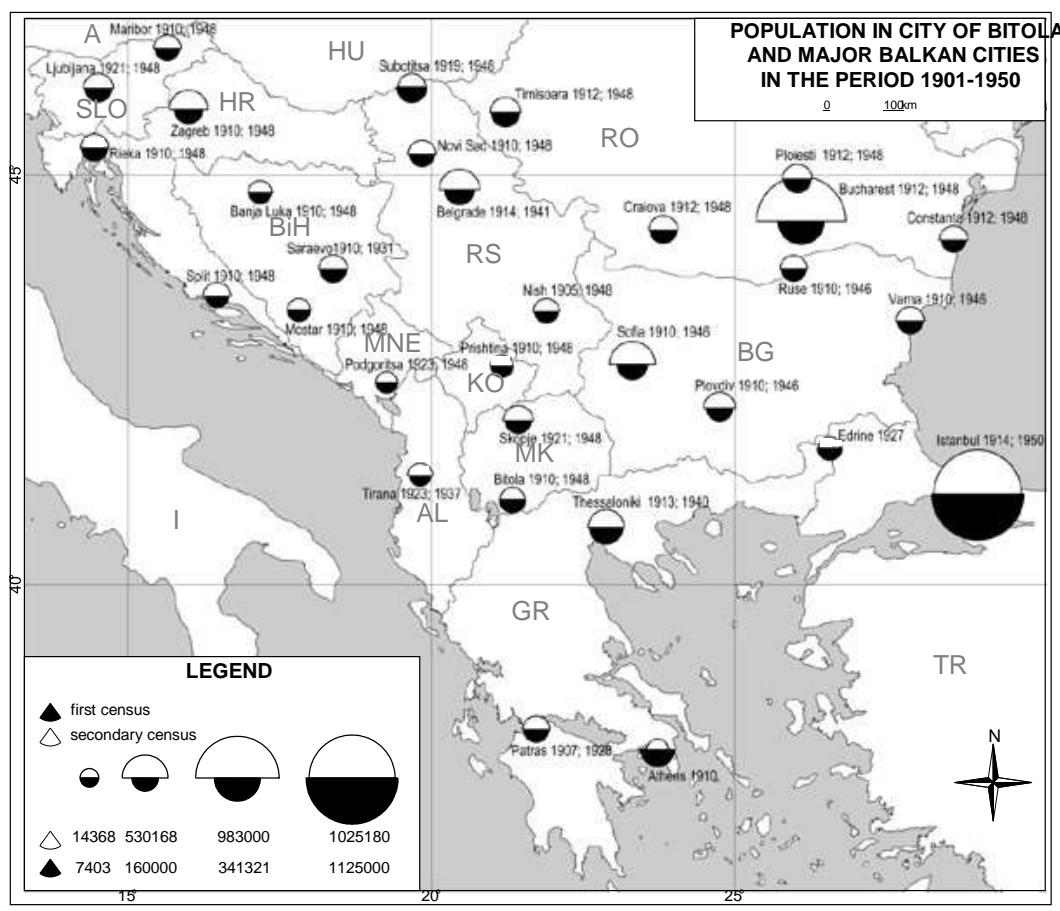


figure 5

Population of the city of Bitola and other major Balkan cities in the period 1901-1950 Source: own elaboration based on relevant census data 


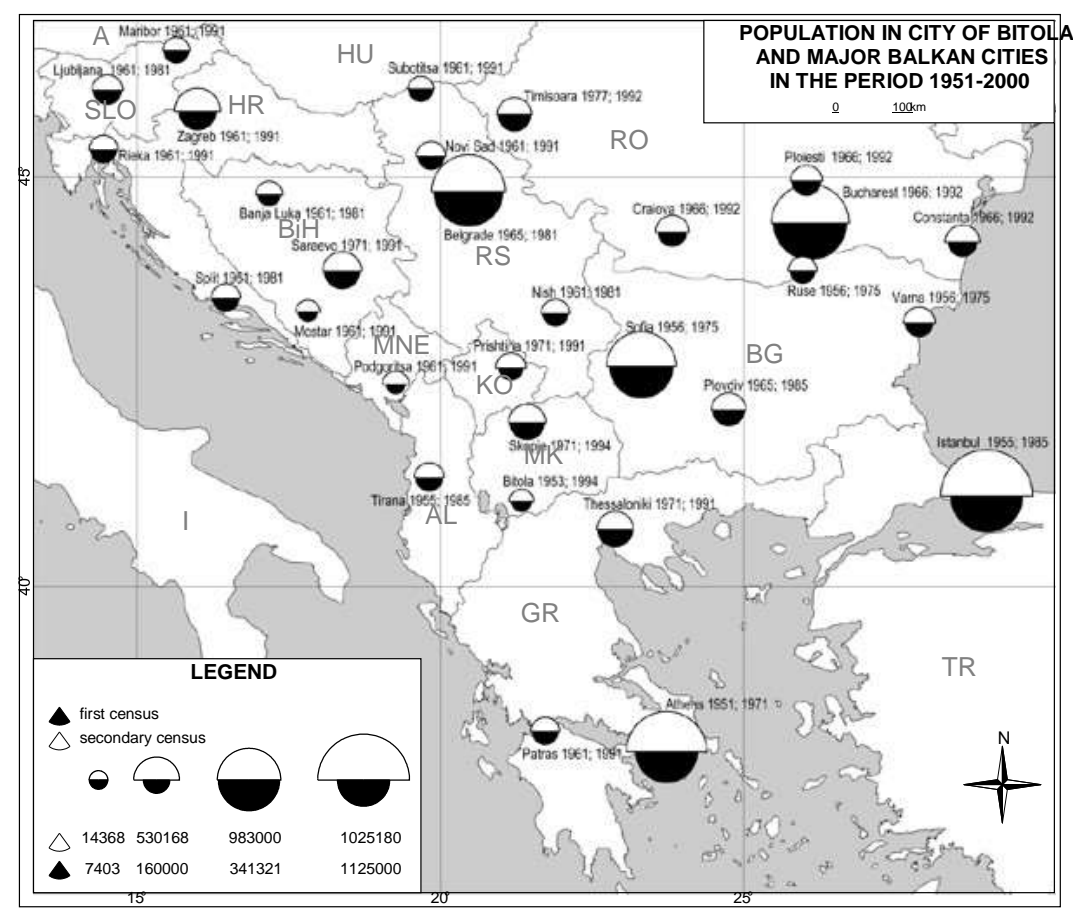

\section{figure 6}

Population in the city of Bitola and other major Balkan cities in the period 1951-2000 Source: own elaboration based on relevant census data

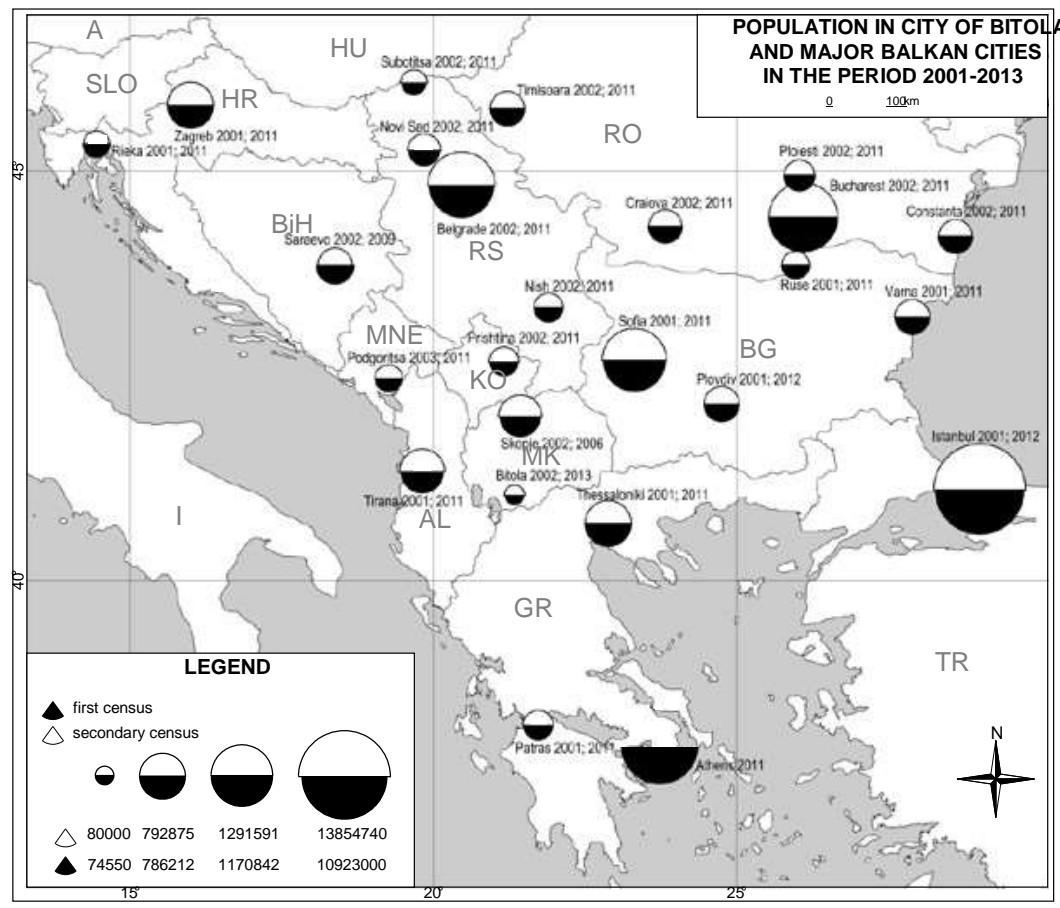

figure 7

Population in the city of Bitola and other major Balkan cities in the period 2001-2013 Source: own elaboration based on relevant census data 
table 4

Population of Bitola and major cities in the Balkans in the period

1901-2013

Source: Relevant Census data for each city 


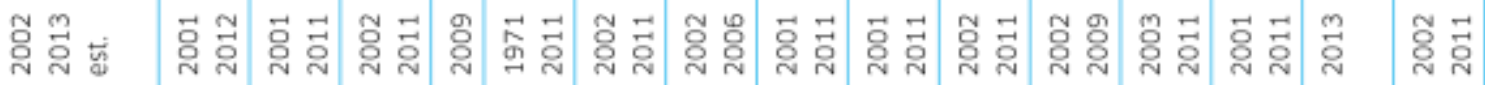<smiles>[C+]1[CH]C=C1</smiles>

啇 状

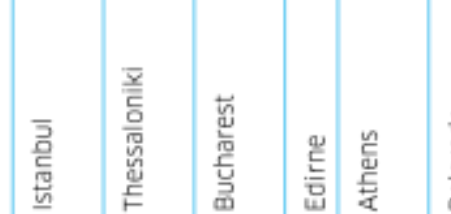

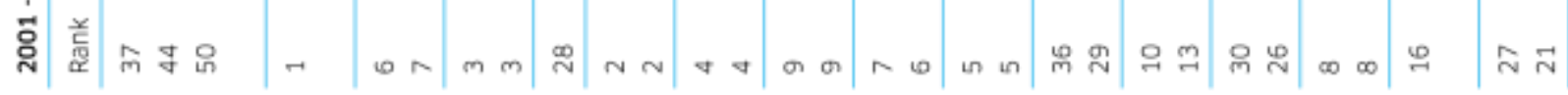

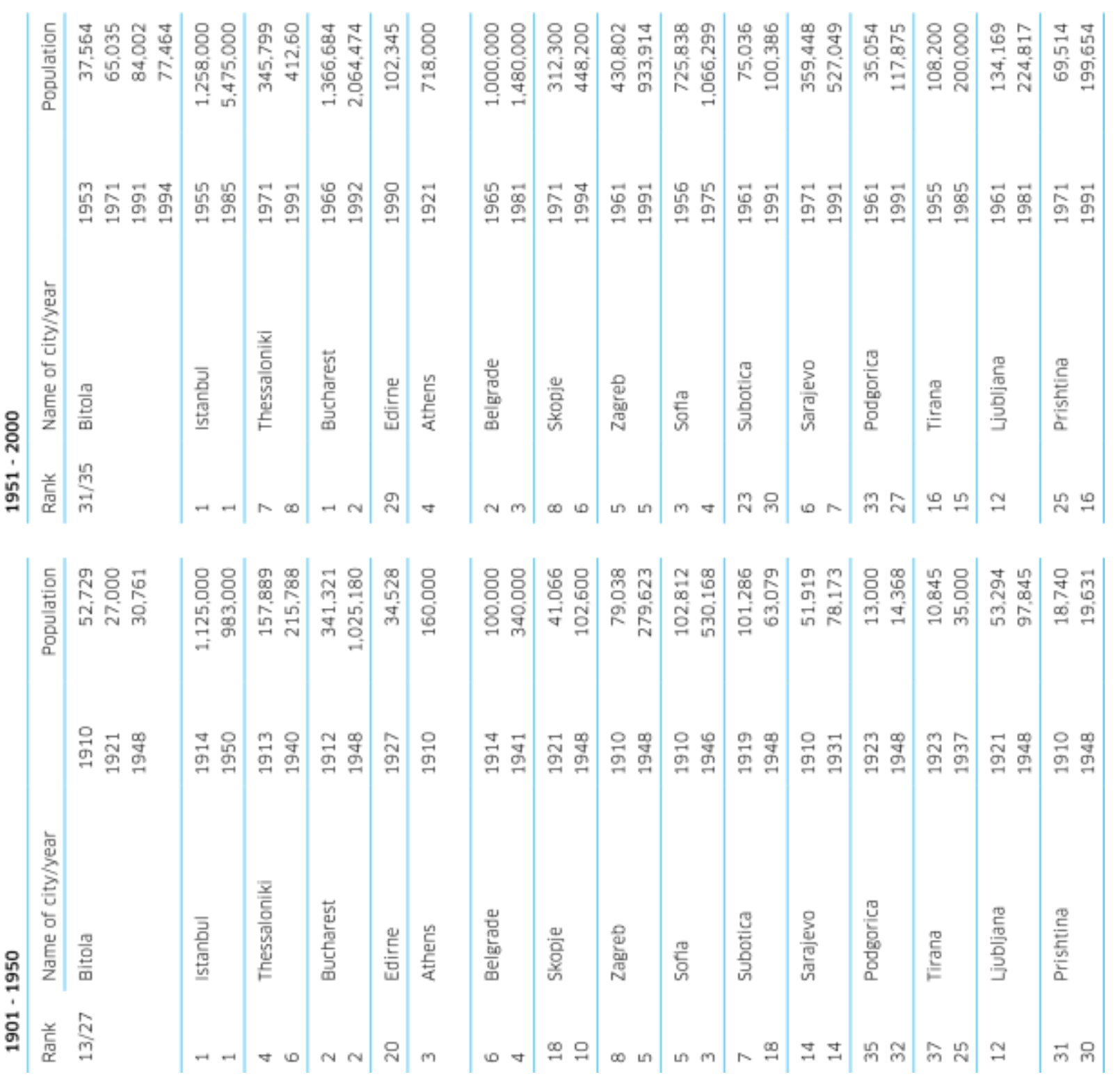




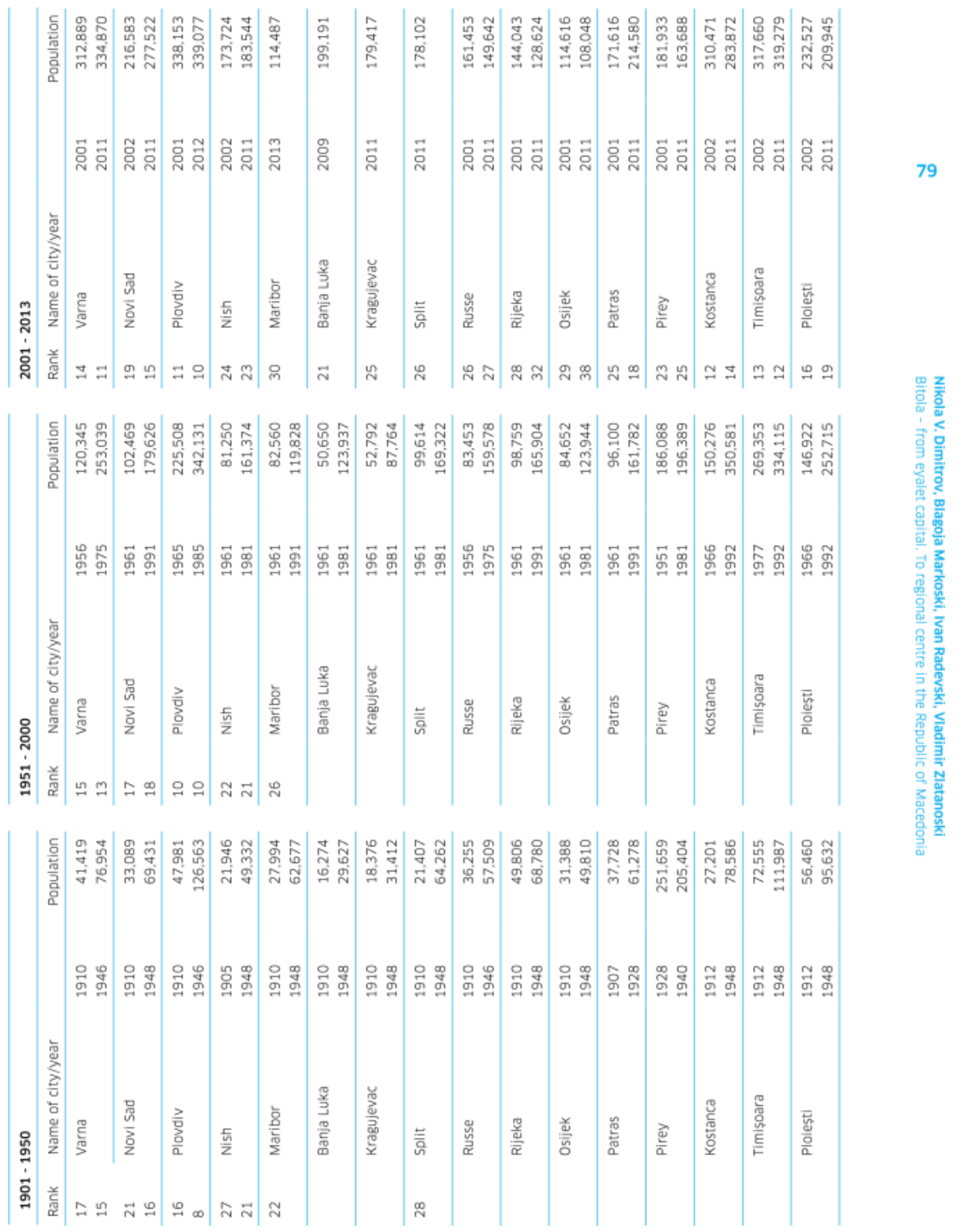


allowed it to become the capital of the Rumelia Eyalet and achieve strong population and economic growth, making it the third most significant city in the Balkans, just after Istanbul and Thessaloniki.

Historical events in the course of the $20^{\text {th }}$ century (the Ilinden uprising in 1903, the Young Turk Revolution, the Balkan wars, WW1, WW2, the post-war period and the period of an independent Republic of Macedonia) resulted in major changes in the geostrategic, administrative and political, as well as the economic position of Bitola. A particular impact is caused by the setting of the country boundaries after the partition of Macedonia in 1913, which made Bitola a peripheral city. Still, it suffered its biggest decline in the first two decades of the $20^{\text {th }}$ century when its population dropped from about 60,000 to about 20,000. Afterwards, Bitola experienced a second growth in population and spatial and administrative influence in the region and today is a modern city with all the functions organised in the country. However, the question of whether Bitola would have advanced in its development had it not been for the events mentioned above, remains constantly open. And that especially if we consider that many Balkan cities were far less developed and significant at a given moment in the past (for example, Sofia, Belgrade, Zagreb, Skopje etc.), and are today population-wise

\section{references}

Birken, A. (1976) Die Provinzen des Osmanischen Reiches. Beihefte zum Tübinger Atlas des Vorderen Orients (Reihe B

(Geisteswissenschaften), 13), Dr. Ludwig Reichert Verlag, Wiesbaden [in German].

Bitoski, K. (1966) Prilog kon proucuvanjeto na Bitolskite esnafi I nivnata opshtestvena uloga vo XIX vek, GINI, G. X, broj 1, 137163 [in Macedonian].

Dimeski, D. (1982) Makedonskoto nacionalnoosloboditelno dvizhenje vo Bitolskiot vilaet (1893-1903), DNUB, Skopje [in Macedonian]. Dimitrov, V. N. \& Ognenovski T. (2009) Bitolski region naselenie i naselbi, Bitola [in Macedonian].

Dimitrov, V. N. (1998) Urbano geografski razvoj na Bitola, Bitola [in Macedonian].

Dimitrov, V. N. (2005) Geografsko-istoriski pregled na stopanskiot podem na Bitola vo XIX vek, Zbornik na trudovi od tribina: Bitola niz vekovite VIII, Bitola vo XIX vek - ekonomski prosperitet, Bitola, 523 [in Macedonian].

Grujoski, T. (1971) Bitola - dejstvoto na osnovnite faktori vrz opshtestveno-ekonomskiot razvoj, Bitola [in Macedonian]. Konstantinov, Hr. M. (1961) Zanaeti I esnafi vo Bitola i okolinata, Naucno drushtvo, Bitola [in Macedonian].

Matkovski, A. \& Angelkova, P. (1974) Patuvanjeto na dvajca anglichani niz Makedonija vo 1839, 1842 i 1844 g., GINI, G. XVIII, broj 1, 236-237 [in Macedonian].
Matkovski, A. (1992) Makedonija vo delata na stranskite patepisci 1864-1874, Misla, Skopje [in Macedonian].

Matkovski, A. (2000) Makedonija vo delata na stranskite patepisci 1864-1874, Skopje [in Macedonian].

and economically more developed than Bitola in multifarious ways. This means that some global geostrategic and political directions of development predetermined a different administrative, political and economic course of development.

The future course of development of Bitola must be seen through the prism of Bitola as a centre of the southwestern part of the Republic of Macedonia, a centre for the north-western territories in Greece and certain territories in Albania that border the territories of the Orhid-Prespa region. Development paths based on the concept of the

European Union should enable this and should do it in such a way that open borders and the construction of infrastructure (road, railway etc.) kick-start the further advancement of Bitola. It is irrational and illogical for one of the largest production regions (Pelagonia) to still be without a highway connecting it to the country's capital and centre Skopje, and for it to have a nonfunctioning railway towards Greece. If that is overcome, then Bitola will once again become a worthy centre of a region which now includes a multitude of cities and settlements: Prilep, Lerin, Resen, Demir-Hisar, Krushevo, Kichevo, Makedonski Brod, Ohrid, Struga, Debar, Pogradec and Korcha - an area of a few thousand $\mathrm{km}^{2}$ and a population of a few hundred thousand.

Matkovski, A. (2001) Makedonija vo delata na stranskite patopisci 1875 1878 g., Gjurgja, Skopje [in Macedonian].

Petkova, M. R. (1993/94) Razvojot na botolskata carshija (do II Svetska vojna), Zbornik na trudovi 4-5, Zavod za zashtita na spomenicite na kulturata I prirodnite retkosti, muzej i galerija, Bitola, 138-139 [in Macedonian].

Poljanski Andonov, Hr. (1972) Kon istorijata na trgovijata na Bitola vo 1856 g., GINI, G. XVI, broj 3, 203-219 [in Macedonian] Poljanski Andonov, Hr. (1982) Britanski dokumenti za istorijata na makedonskiot narod, (volume 3, 1848-1856), Arhiv na Makedonija, Skopje, Dokument br. 90 od 12.02.1852 g. [in Macedonian] Senkevich, I. (1967) M. A. Hitrovoprv ruski konzul vo bitolskiot kraj (1861 - 1864), GINI, G. XI, broj 1, 117118 [in Macedonian] Sotirovski, N. (1966) Eden nepoznat izveshtaj za bitolskiot pashalak od $1856 \mathrm{~g}$. (Glasnik na pravniot fakultet vo Skopje, 10), Skopje, 189190 [in Macedonian].

Savezni zavod za statistiku (Yugoslavia). Total population, households and dwellings, population censuses 1921-1991 State Statistical Office of the Republic of Macedonia, population censuses 1948-2002 
Stamboliska, S. (2005) Izveshtaj za Bitolskiot pashalak na francuskiot vicekonzul vo Bitola i Beleg de Buga od $1856 \mathrm{~g}$, Skopje [in Macedonian].
Turkish documents on Macedonian history (1958), vol. 5 (1827-1839), Skopje.

Ursinus, M. (1991) "Manāstir", The Encyclopedia of Islam, New Edition, vol. 6: Mahk-Mid, BRILL, Leiden and new York, 371-372.

Zografski, D. (1967) Razvitok na kapitalistickite elementi vo Makedonija Monastir Vilayet: http://en.wikipedia.org/wiki/Monastir_Vilayet za vreme na turskoto vladeenje, Skopje [in Macedonian]. [accessed: 15.09.2016]

\section{Internet sources}

Rumelia Eyalet: http://en.wikipedia.org/wiki/Rumelia_Eyalet [accessed: 23.03.2014

World history at KMLA. History of Rumelia: http://www.zum.de/ whkmla/region/balkans/xrumelia.html [accessed: 15.09.2016]
Salonica Vilayet: http://en.wikipedia.org/wiki/Salonica_Vilayet [accessed: 15.09.2016]

Kosovo Vilayet: http://en.wikipedia.org/wiki/Kosovo_Vilayet [accessed: 15.09.2016]

Scutari Vilayet: http://en.wikipedia.org/wiki/Scutari_Vilayet [accessed: 15.09.2016 